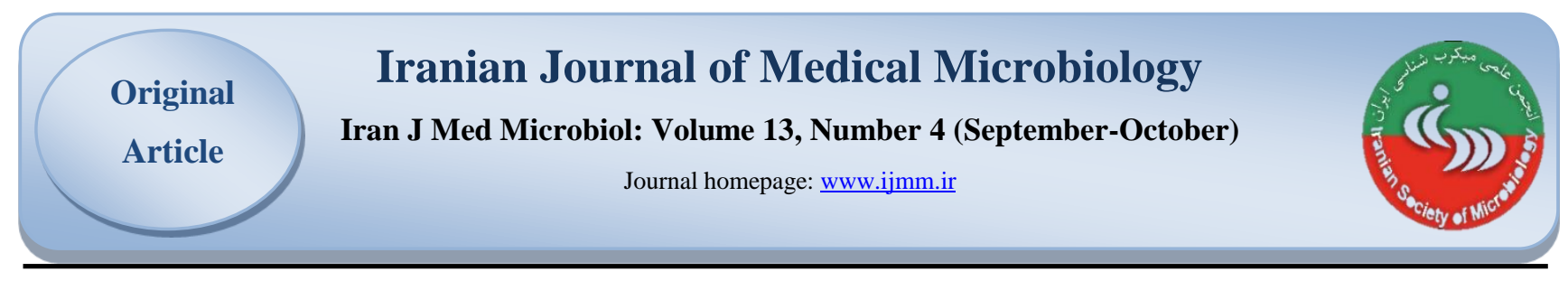

\title{
The Distributions of HCV Genotypes in Hemodialysis Patients in Iraq
}

\author{
Nawfal R Hussein ${ }^{1}$, Eman Sh Al-Obeidy ${ }^{2}$, Ibrahim A. Naqid ${ }^{* 1}$, Kais H Abd ${ }^{3}$, Shakir A. Jamal ${ }^{1}$ \\ 1. College of Medicine, University of Zakho, Zakho, Kurdistan region, Iraq \\ 2. Dialysis Center, Baghdad Medical cities, Baghdad, Iraq \\ 3. Duhok Renal Dialysis Center, Duhok, Kurdistan Region, Iraq
}

\section{Article Information}

\section{Article Subject:}

Virology

do

10.30699/ijmm.13.4.279

Corresponding author:

Ibrahim A. Naqid

College of Medicine, University of Zakho

Email:

Ibrahim.naqid@uoz.edu.krd

Use your device to scan and read the article online

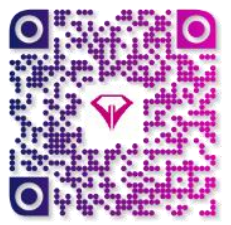

Abstract

Background and Aims: Hepatitis $\mathrm{C}$ virus is a major global health problem that primarily affects the liver which lead to liver cirrhosis, liver failure and hepatocellular carcinoma. The aim of this report was to investigate the genotypes of $\mathrm{HCV}$ in patients on regular hemodialysis in Iraq.

Materials and Methods: A cross sectional study was conducted to investigate the genotypes of HCV in patients on regular hemodialysis in 7 centers across Iraq. A total of 255 subjects with positive anti-HCV antibodies were recruited in this study.

Results: To confirm the positivity, RT-PCR was performed. Amongst all samples, $31 \%$ (79/255) was positive by RT-PCR. Then, we genotyped all the RT-PCR positive samples, it was found that $39 / 79(49.4 \%)$ of our samples were typed as HCV genotype 1 including 26 samples $(66.7 \%)$ as HCV 1a and 13 samples $(33.3 \%)$ as HCV 1b. HCV genotype 4 was found in $34 / 79(43 \%)$ of the samples while $6 / 79(7.6 \%)$ of the samples typed as HCV 3

Conclusion: HCV genotype 1 was the most prevalent genotype followed by genotype 4. Further population-based study is required to investigate the prevalence of HCV genotypes.

Keywords: Genotypes, HCV, Hemodialysis Patients, Iraq

Received: 2019/08/09_Accepted: 2019/10/02 Available online: 2019/10/02

Copyright $\odot$ 2019. This is an open-access article distributed under the terms of the Creative Commons Attribution- 4.0 International License which permits Share, copy and redistribution of the material in any medium or format or adapt, remix, transform, and build upon the material for any purpose, even commercially.

How to cite this article:

Hussein N, Al-Obeidy E S, Naqid I, Abd K H, Abdulrahman S. The Distributions of HCV Genotypes in Hemodialysis Patients in Iraq. Iran J Med Microbiol. 2019; 13 (4) :279-283

Download citation:

$\underline{\text { BibTeX }}|\underline{\text { RIS }}| \underline{\text { EndNote }}|\underline{\text { Medlars }}| \underline{\text { ProCite }}|\underline{\text { Reference Manager }}| \underline{\text { RefWorks }}$

Send citation to:

$\underline{\text { Mendeley } 2}$ zotero $($ RefWorks 


\section{Introduction}

Infection with HCV is a global health issue (1). Currently, more than 200 million subjects are infected with the hepatitis C virus (2). Chronic infection with the virus is associated with deleterious consequences such as liver cirrhosis and hepatocellular carcinoma (3). The prevalence of HCV infection has been studied thoroughly. While the prevalence of $\mathrm{HCV}$ positivity is $0.2 \%$ in blood donners in Iraq, around $4 \%$ of the Pakistani blood donners were positive for the virus (4-6). The prevalence of HCV infection in subjects undergoing hemodialysis differs from developing countries to developed countries. The prevalence of HCV in hemodialysis subjects in Iran, Turkey and Saudi was found to be $4 \%, 11 \%$ and $20 \%$, respectively (7-9). In the UK, the prevalence of $\mathrm{HCV}$ in hemodialysis patients was $2 \%$ and around $20 \%$ in Spain and Italy $(10,11)$. In a study conducted in Iraq recruiting patients on hemodialysis, the prevalence of $\mathrm{HCV}$ was $4.3 \%$ (12). HCV is of six genotypes, labeled 1 through 6 . The heterogeneity of the virus makes the development of vaccine insuperable (13). The heterogeneity of HCV also plays an important role in determining sustained virologic response (SVR) in subjects infected with the virus. The treatment showed greater efficacy in genotype 2 and 3 . Genotypes 1 and 4 are problematic to treatment with less SVR rates (14).

The aim of this study was to investigate the genotype of $\mathrm{HCV}$ in patients on regular hemodialysis in Iraq.

\section{Materials and Methods}

During the study period between May 2017 and May 2019, 255 patients were recruited. Recruiting patients were undergoing regular hemodialysis for renal failure in seven dialysis centers in Medical City Hospital, Al-Karama Teaching Hospital, Al-Kadymia Teaching Hospital -Baghdad, Al-Basra Teaching Hospital, Duhok dialysis center and Zakho dialysis center. A 5cc syringe and needle were used to obtain five $\mathrm{ml}$ of blood from subjects. Then, the samples were centrifuged at $1500 \mathrm{rpm}$ for $3 \mathrm{~min}$ to obtain serum.

\section{ELISA}

The HCV (antibody) Ab was studied using a thirdgeneration immunoassay that allows the detection of antibodies to the NS3, NS4 and NS5 core antigens of the virus (Foresight- USA) following manufacturer's instruction. All tests were performed in duplicate.

\section{RNA extraction and quantification}

RNA was extracted by QIAamp RNA Extraction Kit (Qiagen) according to manufactures instructions and the extracted RNA concentration was confirmed by nanodrop study. Quantification of HCV RNA was performed by real-time quantative PCR-based test (Amplicor HCV test; Hoffman-La Roche, Nutley, NJ, USA). The manufacturer's instructions were followed and the internal control supplied by the manufacturer was added to each specimen, as an extraction and amplification control.

\section{HCV genotyping}

HCV genotyping was performed using a commercial line probe assay (Abbot-USA), according to the manufacturer's instructions. In this assay, after the amplification of the $5^{\prime}$ nontranslated region of the HCV genome, the product was labelled with biotin. Reverse-hybridization reaction was performed with 21 different probes. The hybridization reaction was then reacted with streptavidin-phosphatase conjugate. The reaction identified the 6 major HCV genotypes and their subtypes.

\section{Ethics}

The project was approved by the scientific and ethics committee in the college of Medicine, University of Zakho. Written consent was obtained from recruited subjects.

\section{Results}

\section{Patients and HCV positivity}

During the period from May 2017 to May 2019, 255 hemodialysis patients with positive HCV-Ab results were referred for further evaluation. HCVAb positivity was confirmed again by ELISA. Then, 
to discriminate between current infection and old resolved infection, RT-PCR was performed for all positive samples. The average age of positive samples was $52.9 \pm 12.8$ years. Amongst all samples, 31\% (79/255) was positive by RT-PCR. $34.2 \%(27 / 79)$ of the positive samples were female.

\section{HCV Genotype}

Then, we genotyped all the RT-PCR positive samples, it was found that $39 / 79$ (49.3\%) of our samples were typed as HCV genotype 1 including $66.7 \%(26 / 39)$ samples as HCV 1 a and $33.3 \%$ samples (13/39) as HCV 1b. HCV genotype 4 was found in $34 / 79$ (43\%) of the samples while $6 / 79$ (7.6\%) of the samples typed as HCV 3.

\section{Discussion}

In this study, it was found that $49.3 \%$ of our samples were typed as HCV genotype 1 including 26 samples as HCV 1 a and 13 samples as HCV 1 b. HCV genotype 4 was found in $43 \%$ of the samples while $7.6 \%$ of the samples typed as HCV 3 . In a meta-analysis study conducted to investigate the prevalence of $\mathrm{HCV}$ in Iran the prevalence of HCV was found between $9-12 \%$ according to the technique used for the diagnosis (9). In another study conducted in Turkey, $20 \%$ of the recruited subjects were positive for HCV (8). In a study conducted in Iraq, HCV positivity was found to be 4.3\% (12). Previously, different studies investigated $\mathrm{HCV}$ genotype in Iraq. In a study conducted in the southern region, $50 \%$ of the recruited samples typed as genotype 1 followed by $35 \%$ for genotype 4 (15). In studies that had recruited patients with thalassemia from northern Iraq, it was found that HCV genotype 4 is the most prevalent genotype followed by genotype 1 (16, 17). In another study investigating the HCV genotypes in patients with end stage kidney diseases in Iraq, HCV genotype 1a was found in all patients (18). Reports from the Arab peninsula showed that genotype 4 was the most prevalent $\mathrm{HCV}$ genotype $(19,20)$. Infections with HCV genotype 4 and 1 are the most difficult to treat. In Iraq, it was previously shown that, $50 \%$ of the patients infected with HCV genotypes 1 and 4 responded to the classical treatment containing interferon (16). Direct acting antivirals are new potent medications but very expensive in Iraq therefore strict infection control measurement should be imposed to prevent the transmission of the virus particularly in hemodialysis patients. Studying HCV genotypes may provide a useful tool for tracking the source of HCV infection and it provides evidence for a patient to patient transmission. Additionally, studying HCV genotypes may help understanding the prognosis of the disease. It was previously found that infection with HCV 1b genotype was associated aggressive course of the disease (21). Furthermore, a possible link between HCV $1 b$ genotype and hepatocellular carcinoma has been proposed (21). Therefore, studying HCV genotypes is importance particularly in vulnerable groups such as patients on hemodialysis and priority should be given to patients who are infected with virulent genotypes.

Our study has limitations. We studied HCV genotypes in few centers in Iraq. Continuous monitoring of the patients is mandated with regular check of HCV genotypes. HCV genotypes in hemodialysis patients might not reflects the genotypes in the population but certainly is important for monitoring outbreaks in such patients group A population-based project is suggested to investigate $\mathrm{HCV}$ in this society. However, the prevalence of HCV may be low in the population making the study of HCV genotype extremely difficult.

\section{Conclusion}

To conclude, HCV genotype 1 was the most common genotype in this study. This is in agreement with previous reports in Iraq. A population-based study is needed to determine HCV genotypes in the country.

\section{Acknowledgements}

We would like to thanks the staff of central labs and dialysis centers for their continuous support during the study. 


\section{Conflict of Interest}

The authors reported no conflict of interest.

\section{References}

1. Flichman DM, Blejer JL, Livellara BI, Re VE, Bartoli S, Bustos JA, et al. Prevalence and trends of markers of hepatitis $B$ virus, hepatitis $C$ virus and human Immunodeficiency virus in Argentine blood donors. BMC infectious diseases. 2014;14(1):218. [DOI:10.1186/1471-2334-14-218]

[PMID] [PMCID]

2. Zaheer H, Saeed U, Waheed Y, Karimi S, Waheed U. Prevalence and Trends of Hepatitis B, Hepatitis $\mathrm{C}$ and Human Immunodeficiency Viruses among Blood Donors in Islamabad, Pakistan 2005-2013. J Blood Disorders Transf. 2014;5(217):2.

3. Walter SR, Thein H-H, Amin J, Gidding HF, Ward $\mathrm{K}$, Law MG, et al. Trends in mortality after diagnosis of hepatitis B or C infection: 1992-2006. Journal of hepatology. 2011;54(5):879-86. [DOI:10.1016/j.jhep.2010.08.035] [PMID]

4. Afzal MS, Ahmed T, Zaidi NuSS. Comparison of HCV Prevalence in Pakistan and Iran; An Insight into Future. Hepatitis Monthly. 2014;14(1):e11466. [DOI:10.5812/hepatmon.11466]

5. Kafi-Abad SA, Rezvan H, Abolghasemi H. Trends in prevalence of hepatitis B virus infection among Iranian blood donors, 1998-2007. Transfusion Medicine. 2009;19(4):189-94. [DOI:10.1111/j.1365-3148.2009.00935.x] [PMID]

6. Hussein NR, Haj SM, Almizori LA, Taha AA. The Prevalence of Hepatitis B and C Viruses Among Blood Donors Attending Blood Bank in Duhok, Kurdistan Region, Iraq. International Journal of Infection. 2016;4(1):e39008. [DOI:10.17795/iji$39008]$

7. Karkar A. Hepatitis C in dialysis units: The Saudi experience. Hemodialysis International. 2007;11(3):354-67. [DOI:10.1111/j.15424758.2007.00192.x] [PMID]

8. Yakaryilmaz F, Alp Gurbuz O, Guliter S, Mert A, Songur Y, Karakan T, et al. Prevalence of Occult Hepatitis B and Hepatitis C Virus Infections in Turkish Hemodialysis Patients. Renal Failure. 2006;28(8):729-35.

[DOI:10.1080/08860220600925602] [PMID]

9. Ghorbani NR, Djalalinia S, Modirian M, Abdar ZE, Mansourian M, Gorabi AM, et al. Prevalence of hepatitis $\mathrm{C}$ infection in Iranian hemodialysis patients: An updated systematic review and metaanalysis. J Res Med Sci. 2017;22:123-. [DOI:10.4103/jrms.JRMS 223 17] [PMID] [PMCID]
10.Barril G, Traver JA. Decrease in the hepatitis C virus $(\mathrm{HCV})$ prevalence in hemodialysis patients in Spain: effect of time, initiating HCV prevalence studies and adoption of isolation measures. Antiviral Research. 2003;60(2):129-34. [DOI:10.1016/j.antiviral.2003.08.008] [PMID]

11.Gallego E, López A, Pérez J, Llamas F, Lorenzo I, López E, et al. Effect of Isolation Measures on the Incidence and Prevalence of Hepatitis C Virus Infection in Hemodialysis. Nephron Clinical Practice. 2006;104(1):c1-c6. [DOI:10.1159/000093252] [PMID]

12.Ibrahim NM, Saleem ZSM, Hussein NR. The Prevalence of HIV, HCV, and HBV among hemodialysis patients attending Duhok Hemodialysis Center. International Journal of Infection. 2018;5(1). [DOI:10.5812/iji.63246]

13.Te HS, Jensen DM. Epidemiology of Hepatitis B and C Viruses: A Global Overview. Clinics in Liver Disease. 2010;14(1):1-21. [DOI:10.1016/j.cld.2009.11.009] [PMID]

14.Legrand-Abravanel F, Colson P, LeguillouGuillemette H, Alric L, Ravaux I, Lunel-Fabiani F, et al. Influence of the HCV subtype on the virological response to pegylated interferon and ribavirin therapy. Journal of Medical Virology. 2009;81(12):2029-35. [DOI:10.1002/jmv.21583] [PMID]

15.Al-Kubaisy W, Al-Naib K, Habib M. Seroprevalence of hepatitis $\mathrm{C}$ virus specific antibodies among Iraqi children with thalassaemia. East Mediterr Health J 2006;12(1-2):204-10.

16. Hussein NR, Tunjel I, Basharat Z, Taha A, Irving $\mathrm{W}$. The treatment of $\mathrm{HCV}$ in patients with haemoglobinopathy in Kurdistan Region, Iraq: a single centre experience. Epidemiology and Infection. 2016;144(08):1634-40. [DOI:10.1017/S0950268815003064] [PMID]

17. Hussein NR. The efficacy and safety of Sofosbuvircontaining regimen in the treatment of $\mathrm{HCV}$ infection in patients with haemoglobinopathy. Mediterranean journal of hematology and infectious diseases. 2017;9(1). [DOI:10.4084/mjhid.2017.005] [PMID] [PMCID]

18.Hussein NR, Saleema ZS, Abd QH. Direct Acting Antiviral Treatment for Patients with End-Stage Kidney Disease with Acute HCV Infection. Mediterranean journal of hematology and infectious diseases. 2019;11(1). [DOI:10.4084/mjhid.2019.034] [PMID] [PMCID]

19. Koshy A, Madda JP, Marcellin P, Martinot M. Treatment of Hepatitis C Virus Genotype 4 Related Cirrhosis: Ribavirin and Interferon Combination Compared With Interferon Alone. Journal of 
Clinical Gastroenterology. 2002;35(1):82-5. [DOI:10.1097/00004836-200207000-00017] [PMID]

20.Ohno T, Mizokami M, Saleh MG, Orito E, Ohba KI, $\mathrm{Wu} \mathrm{RR}$, et al. Usefulness and limitation of phylogenetic analysis for hepatitis $\mathrm{C}$ virus core region: application to isolates from Egyptian and Yemeni patients. Archives of Virology. 1996;141(6):1101-13. [DOI:10.1007/BF01718613] [PMID]

21.Zein NN. Clinical significance of hepatitis $C$ virus genotypes. Clin Microbiol Rev. 2000;13(2):223-35. [DOI:10.1128/CMR.13.2.223] [PMID] [PMCID] 